To cite this article: Kavurt S, Iyigun F, Demirel N, Ulubas Isik D, Ozdemirci S, Bas AY. Evaluation of cord blood ischemia modified albumin and mean platelet volume in infants of preeclamptic mothers. Turk J Womens Health Neanotol 2021; 3(4): 87-92

- Original Article

\title{
Evaluation of Cord Blood Ischemia Modified Albumin and Mean Platelet Volume in Infants of Preeclamptic Mothers
}

\section{Preeklamptik Annelerin Bebeklerinde Kordon Kanı Iskemi Modifiye Albümin Düzeyleri ve Ortalama Trombosit Hacminin Değerlendirilmesi}

Sumru Kavurt ${ }^{1 *} \square$ Fatma İyigün ${ }^{2} \square$ Nihal Demirel ${ }^{3} \square$, Dilek Ulubas Isık ${ }^{1} \square$, Safak Özdemirci ${ }^{4} \square$ Ahmet Yagmur Bas 3 回

${ }^{1}$ Department of Neonatology, University of Health Sciences, Etlik Zubeyde Hanım Women's Health Training and Research Hospital, Ankara, Turkey

${ }^{2}$ Department of Neonatology, Yozgat City's Hospital, Yozgat, Turkey

${ }^{3}$ Department of Neonatology, Yıldırım Beyazıt University, Ankara, Turkey

${ }^{4}$ Bandırma Royal Hospital, Department of Obstetrics and Gynecology, Bandırma, Turkey

\begin{abstract}
Aim: Oxidative stress (OS) is a known cause of placental dysfunction, thus may be causally related to preeclampsia and small for gestational age infant (SGA). We aimed to investigate cord blood ischemia-modified albumin (IMA) and mean platelet volüme (MPV) levels in neonates born to mothers with preeclampsia and correlate the determined levels with beeing SGA.

Material and Method: A prospective controlled study was conducted. Fifty infants of mothers with preeclampsia, 40 healthy neonates of healthy mothers were included. Cord blood IMA and MPV levels were measured in infants of mothers with preeclampsia. The role of cord blood IMA levels to predict beeing SGA was also investigated.

Results: Cord blood IMA and MPV levels of infants of preeclamptic mothers were significantly higher compared to controls. Serum IMA levels were significantly higher in SGA infants compared to appropirate for gestational age (AGA) infants $(p=0.018)$, however MPV levels were similar in both groups $(p=0.735)$.

Conclusion: According to this study cord blood IMA and MPV levels may be considered useful as a simple measure of OS status in infants of mothers with preeclampsia. However, further studies with larger samples will be necessary to determine usefulness of these markers in clinical practice.
\end{abstract}

Keywords: oxidative stress; ischemia modified albumin; newborn; preeclampcia

Corresponding Author *: Sumru Kavurt, MD, Department of Neonatology, University of Health Sciences, Etlik Zubeyde Hanım Women's Health Teaching and Research Hospital, Yeni Etlik Caddesi, 06210, Ankara, Turkey

e-mail: sumrukavurt@gmail.com

ORCID: 0000-0003-0329-1846

DOI: $10.46969 /$ ezh.1039409

Geliş tarihi: 22.12.2021

Kabul tarihi: 29.12 .2021 


\section{Öz}

Amaç: Oksidatif stres (OS), plasental disfonksiyonun bilinen bir nedenidir, bu nedenle preeklampsi ve gestasyon haftasına göre düşük doğum ağırlığı ile nedensel olarak ilişkili olabilir. Preeklampsili annelerden doğan yenidoğanlarda kordon kanı iskemi modifiye albumin (IMA) ve ortalama trombosit hacmi (MPV) düzeylerini araştırmayı ve belirlenen düzeylerin gestasyon haftasına göre düşük doğum ağırlığı ile ilişkisini değerlendirmeyi amaçladık.

Gereç ve Yöntem: Prospektif kontrollü olan bu çalışmaya annesinde preeklampsi olan 50 bebek ve sağlıklı annelerin 40 sağlıklı yenidoğanı dahil edildi. Preeklampsili annelerin bebeklerinde kordon kanı iMA ve MPV düzeyleri ölçüldü. Kordon kanı İMA düzeylerinin gestasyon haftasına göre düşük doğum ağılığı olma durumunu öngörmedeki rolü de araştırıldı.

Bulgular: Preeklamptik annelerin bebeklerinin kordon kanı IMA ve MPV düzeyleri kontrollere göre anlamlı derecede yüksekti. Serum IMA düzeyleri gestasyon haftasına göre düşük doğum ağırlığı olan bebeklerde, doğum ağılığı gestasyonel yaşa uygun (AGA) bebeklere göre anlamlı olarak yüksekti $(p=0,018)$, ancak MPV düzeyleri her iki grupta da benzerdi $(p=0,735)$.

Sonuç: Bu çalışmaya göre, preeklamptik annelerin bebeklerinde kord kanı iMA ve MPV düzeylerinin OS durumunun basit bir ölçümü olarak yararlı olduğu düşünülebilir. Bununla birlikte, bu belirteçlerin klinik pratikteki yararlılığını belirlemek için daha büyük örneklemli daha ileri çalışmalar gerekli olacaktır.

Anahtar kelimeler: oksidatif stres; iskemi modifiye albümin; yenidoğan; preeklampsi

\section{Introduction}

Preeclampsia (PE) is a common pregnancy specific disease with potential adverse maternal and neonatal outcomes (1, 2). Placental and maternal vascular oxidative stress due to an imbalance between prooxidants and antioxidants play a key role in PE (3).

Preeclampsia, characterized by decreased uteroplacental blood flow and placental dysfunction, is a significant risk factor for a preterm and small for gestational age infant (SGA). Oxidative stress (OS), is a known cause of placental dysfunction, thus may be causally related to preeclampsia and SGA (3-5).

Ischemia-modified albumin (IMA) is an oxidatively modified form of albumin which has been introduced recently in the evaluation of the OS in several diseases (6). Many reports have demonstrated that serum IMA levels are significantly higher in moderate and severe PE compared to the normal pregnancy as a simple measure of elevated OS status $(7,8)$.

MPV is the measure of the average volume of circulating platelets and used as a marker for platelet function and activation (9). Platelet activation and destruction is well recognized feature of PE $(10,11)$. Since PE triggers OS and MPV shows thrombocyte response to stress, it might be used as OS marker. The predictive ability of MPV for adverse neonatal outcomes and hypertensive disorders has been investigated with conflicting results $(12,13)$. Placental hypoxia and OS are implicated in the pathogenesis of PE which may lead to maternal and fetal complications (3), so measurement of serum and cord blood IMA and MPV levels in preeclamptic mothers and their babies could be useful as a simple measure of OS status.

Data related to the role of IMA in preeclmaptic mothers and their babies is limited, none is present for MPV. We hypothesize that neonates born to preeclamptic mothers have elevated cord blood IMA nad MPV levels which could be associated with oxidative stress status. To our knowledge tihs is the first stduy that investigated cord blood IMA and MPV levels born to preeclamptic mothers and their relationship with development of SGA.

Therefore, we aimed to investigate cord blood IMA and MPV levels in neonates born to mothers with preeclampsia and correlate the determined levels with beeing SGA.

\section{Material and Method}

\section{Study Design}

A prospective controlled study was conducted in neonatal intensive care unit (NICU) at Etlik Zubeyde Hanım Women's Health Teaching and Research Hospital, Ankara, Turkey between March 2019 and March 2020. Neonates born to preeclamptic mothers were enrolled. Birth weight (BW) and gestational age (GA) matched healthy neonates born to healthy mothers were taken as controls. Deliveries were performed either vaginally or by caesarean section. One and five minute Apgar scores were $\geq 8$ and umbilical cord ph values were $\geq 7.25$ in both groups. Neonates with symptoms of intrauterine infection or stigmate 
of genetic syndromes and major congenital malformations were excluded from the study. The study was approved by the Local Ethics Committess, and informed written consent was obtained from the parents before enrollment.

All participants' rights were protected and a written informed consents were obtained before the procedures according to the Helsinki Declaration.

\section{Clinical Data}

Clinical data including GA, BW, head circumference, lenght, 1 and 5 minute Apgar score, complete physical examination were recorded. Gestational age was calculated according to New Ballard Score. Small for gestational age (SGA) was defined as birth weight below 10 th percentile according to intrauterine growth charts of Usher and McClean (14). Laboratory data including complete blood count (CBC) was also recorded.

Preeclampsia was defined as onset of hypertension (140/90 $\mathrm{mmHg}$ at two different measurements at least $4 \mathrm{~h}$ apart) and proteinuria (300mg/d or more) after 20 weeks of gestation (11). Pregnant womens with long standing chronic diseases (e.g: cardiac diseases, hypertension and kidney diseases), smokers and those with active infection or chorioamnionitis were excluded.

The primary outcome was difference in serum IMA and MPV values between infants of preeclamptic mothers and healthy controls. Secondary outcomes were the association of IMA and MPV levels with beeing SGA.

\section{IMA and MPV Measurements}

Five mililiters of umbilical venous blood were obtained just after delivery and were divided into; three mililiters of sterile EDTA vacutainer to be used in determination of IMA and two mililiters in sterile vacutainer for measurement of CBC. Samples were centrifuged at $5000 \mathrm{rpm}$ for 10 minutes and supernatants were stored at $-80^{\circ} \mathrm{C}$ until analysis.

IMA levels were determined according to the method defined by Bar-Or et al (6). Briefly, $200 \mathrm{uL}$ serum was added to $50 \mathrm{uL} 0.1 \%$ (w/v) cobalt chloride (Sigma Aldrich, St. Louis, $\mathrm{MO} ; \mathrm{CoCl} 2,6 \mathrm{H}_{2} \mathrm{O}$ ). After shaking, 10 minutes were waited to allow cobalt binding to albumin. Then $50 \mathrm{uL}$ dithiothreitol (Sigma) was added as a colouring agent. As control, 50 uL of distilled water was used instead of dithiothreitol. After 2 minutes $1 \mathrm{~mL}$ of $0.9 \% \mathrm{NaCl}$ was added to stop the reaction, and the absorbance at $470 \mathrm{~nm}$ was determined using a spectrophotometer. The difference of absorbance units between controls and ditihothreitol samples were recorded. The results were quantified as absorbance units (ABSU).

EDTA blood samples were used for identification the MPV (CellDYN 3700).

\section{Statistical Analysis}

Statistical analysis was conducted using the SPSS version 17.0 (SPSS Inc, Chicago, IL). The results are presented as numbers (n), frequencies (\%), means with respective standard deviation (SD) and medians. The boxes in the figures represent mean $\pm S D$ and interquartile ranges. Non- parametric tests were used to analyze continuous variables. Chi-square test was used to compare categorical variables. Statistical significance was considered as $p<0.05$. Receiver operating characteristic (ROC) curve was used for determination of the best discriminative cut off values of IMA to predict risk of beeing SGA in infants of mothers with preeclampsia.

\section{Results}

Fifty neonates of preeclamptic mothers and 40 healthy controls were enrolled to study. Mean GA and BW of the infants of patients were $32.86 \pm 2.6$ weeks and $1976 \pm 616$ grams, respectively. Demographic characteristics of patients and controls were similar (Table 1 ). In this study 10 (20\%) neonates born to mothers with PE were SGA.

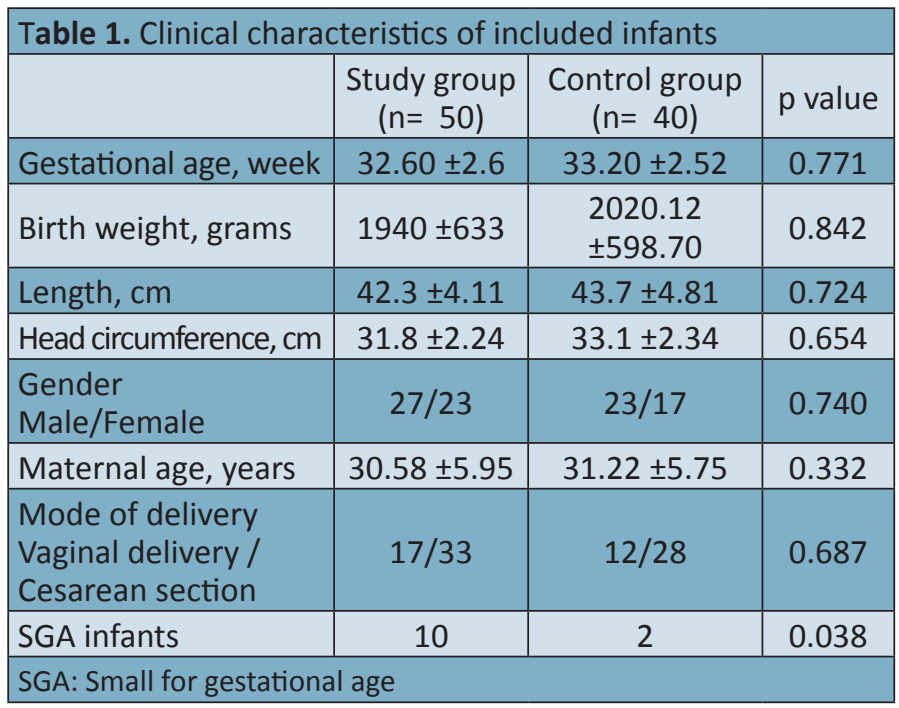

Cord blood IMA levels of infants of preeclamptic mothers were significantly higher compared to controls $(p=0.02)$. The mean IMA value was $1.01 \pm 0.08$ absorbance units (ABSU) in infants of mothers with PE and $0.94 \pm 0.09 \mathrm{ABSU}$ in the control group. Similarly, cord blood MPV levels of infants of preeclamptic mothers were significantly higher than infants in the control group. The mean MPV value was $7.8 \pm 1.2 \mathrm{fl}$ in infants of mothers with preeclampsia and $7.4 \pm 1.01 \mathrm{fl}$ in the control group. Platelet values were significantly decreased in infants of preeclamptic mothers compared to controls $(p<0.013)$. There was no significant difference between the groups in means of leukocyte and hemoglobin values. Hematological parameters 
and cord blood IMA levels of the infants of the preeclamptic mothers and controls are given at Table 2.

\begin{tabular}{|c|c|c|c|}
\hline & $\begin{array}{l}\text { Study Group } \\
\qquad(n=50)\end{array}$ & $\begin{array}{l}\text { Control Group } \\
\qquad(n=40)\end{array}$ & $p$ value \\
\hline WBC & $8980 \pm 2760$ & $9350 \pm 3140$ & 0.072 \\
\hline $\mathrm{Hb}$ & $17.3 \pm 2.2$ & $17.1 \pm 2.5$ & 0.573 \\
\hline $\mathrm{Htc}$ & $52.62 \pm 5.67$ & $51.35 \pm 6.62$ & 0.312 \\
\hline Trombosit & $\begin{array}{l}196000 \pm \\
71000\end{array}$ & $\begin{array}{l}219000 \\
\pm 73000\end{array}$ & 0.013 \\
\hline MPV (fl) & $7.8 \pm 1.2$ & $7.4 \pm 1.01$ & 0.03 \\
\hline IMA (ABSU) & $1.01 \pm 0.08$ & $0.94 \pm 0.09$ & 0.02 \\
\hline \multicolumn{4}{|c|}{$\begin{array}{l}\text { WBC: White Blood Cell, Hb: Hemoglobin, Htc: Hematocrit, } \\
\text { MPV: mean platelet volume, IMA: ischemia-modified albümin }\end{array}$} \\
\hline
\end{tabular}

We performed subgroup analysis of cord blood IMA and MPV values of SGA infants. Serum IMA levels were significantly higher in SGA infants compared to appropirate for gestational age (AGA) infants (1.05 \pm 0.09 vs $0.97 \pm 0.09, p=0.018)$, however MPV levels were similar in both groups $(p=0.735)$ (Table 3$)$.

Table 3. Comparison of the means of serum IMA levels of the neonates born SGA and non SGA

\begin{tabular}{|l|c|c|c|}
\hline & $\begin{array}{c}\text { Study Group } \\
(n=50)\end{array}$ & $\begin{array}{c}\text { Control Group } \\
(n=40)\end{array}$ & p value \\
\hline IMA (ABSU) & $1.05 \pm 0.09$ & $0.97 \pm 0.09$ & 0.018 \\
\hline MPV (fl) & $7.76 \pm 1.16$ & $7.64 \pm 1.15$ & 0.735 \\
\hline $\begin{array}{l}\text { IMA: ischemia-modified albümin, MPV: mean platelet volume, SGA: } \\
\text { small for gestational age }\end{array}$
\end{tabular}

Receiver-operating characteristic (ROC) curve analysis was used to examine the value of IMA associated with beeing SGA. The cut off level of $0.98 \mathrm{ABSU}$ for IMA offered the best predictive value for beeing SGA among infants of preeclamptic mothers with a sensitivity of $88.3 \%$ and a specificity of $48 \%$.

\section{Discussion}

In this study we assessed the oxidant status of infants of preeclamptic mothers. As preeclampsia is a systemic inflammatory disease triggering OS in pregnancy, it could be reasonable to evaluate preeclamptic mothers' babies. We measured the cord blood IMA and MPV levels and found that cord blood IMA and MPV levels were significantly higher in infants of preeclamptic mothers compared to controls. High IMA levels indicates that preeclampsia is associated with increased OS as shown in previous studies $(5,7)$.

Preeclampsia is incompletely solved pregnancy complication that causes multi-system disordes. Plasental hypoxia and OS are implicated in the pathogenesis which causes maternal and fetal complications. Many studies have demonstrated that oxidative stress is an important contributing factor in the pathogenesis of vascular damage in preeclampsia $(5,8)$. However, evidence on newborns is limited. Recent research supports the investigation of novel biomarkers to identify oxidative stress status of these babies.

Serum ischemia modified albumin is a new biomarker of tissue ischemia but afterwards, elevated concentrations of IMA were widely reported in non-cardiac diseases associated with OS (6, 15). Furthermore, elevated maternal serum IMA levels have been recently demonstrated in early normal pregnancy, supporting the hypothesis that pregnancy is always associated with immense stress in order to accommodate the increasing demands of the developing fetus (16). Then, OS has been reported to be notable in the development of PE and IMA has been reported as a novel predictive biomarkker for $\mathrm{PE}$ to reflect the OS in the pathogenesis (8) and some studies have demonstrated the correlation of serum IMA with severity of preeclampsia $(7,17)$. In our study increased cord blood IMA levels of infants of preeclamptic mothers are indicative of higher OS status. However we could not assess the correlation between cord blood IMA levels and severity of preeclampsia as the patients with severe PE low. Besides elevated serum IMA levels in normal pregnancy, elective cesarean section was also reported to be associated with increased IMA levels (8). We did not perform correlation analysis to assess the relation between serum IMA levels and mode of delivery in this study because cesarian section was predominate mode of delivery for maternal indication.

Babies born to preeclamptic mothers may have complications due to prematurity and intrauterine growth restriction. Uteroplacental ischemia is the main problem for the fetus in pregnancies complicated with preeclampsia (4). As serum IMA levels are indicative of ischemia, IMA levels should be increased in IUGR infants. However conflicting results are reported about the concentration of cord blood IMA in IUGR infants (1719). In this study, we found that cord blood IMA levels were significantly higher in SGA infants than AGA infants. Also, we evaluated the role of cord blood IMA levels to predict the beeing SGA. The predictive value of cord blood IMA levels to beeing SGA offered a sensitivity of $88.2 \%$ and a specifitiy of $\% 48$ in our study. However, size of the cohort sample is limited, specifity value is low, so additional studies are needed to demonstrate the relationship of serum IMA levels and beeing SGA in infants of mothers with preeclampsia.

Mean platelet volume (MPV) is measured during the complete blood count as an indicator of platelet size, it is indirect measurement of platelet activation. Previous studies reported increased MPV levels in preeclampsia but the 
mechanism is not clear $(13,20)$. Endothelial damage, rather than coagulation, is considered as main reason. Investigations about MPV levels in preeclampsia have hypothesized that increased MPV levels might be a consequence deterioation of microcirculation because of endothelial damage, this causes microthrombi formation and increases platelet turnover, so younger thrombocytes enter the circulation $(20,21)$. Besides it has been reported that high MPV levels may predict a poor outcome following the evelopment of preeclampsia, and that may be used as a marker of OS. Based on these observations we asssesed cord blood MPV levels in infants of preeclamptic mothers to evaluate OS status. We observed that MPV levels were significantly increased, platelet levels were decreased in infants of preeclamptic mothers compared to controls. In general, changes in MPV values reflect platelet turnover, which is altered in responce to systemic inflammation. High levels of MPV were reported to be associated with complications of prematurity in newborns $(12,22)$. However these results are not enough to conclude an exact association.

In conclusion, in this study it has been shown that, cord blood IMA nad MPV levels in infants of mothers with preeclampsia are significantly increased. Also, cord blood IMA levels were significantly higher in SGA infants than AGA infants. So, according to our results cord blood IMA and MPV levels may be considered useful as a simple measure of OS status in infants of mothers with preeclmapsia. However, further studies with larger samples will be necessary to determine usefulness of these markers in clinical practice.

\section{Declaration of Interest}

The authors report no conflicts of interest.

\section{References}

1. Hutcheon JA, Lisonkova S, Joseph KS. Epidemiology of preeclampsia and the other hypertensive disorders of pregnancy. Best Pract Res Clin Obstet Gynaecol 2011; 25:391-403.

2. Abalos E, Cuesta C, Grosso AL, Chou D, Say L. Global and regional estimates of preeclampsia and eclampsia: a systematic review. Eur J Obstet Gynecol Reprod Biol 2013; 170:1-7.

3. Hung $\mathrm{TH}$, Burton GJ. Hypoxia and reoxygenation: a possible mechanism for placental oxidative stress in preeclampsia. Taiwan J Obstet Gynecol 2006; 45:189-200.

4. Kaufmann P, Black S, Huppertz B. Endovascular trophoblast invasion: implications for the pathogenesis of intrauterine growth retardation and preeclampsia. Bio Reprod 2003; 69: 1-7.

5. Dekker GA, Sibai BM. Etiology and pathogenesis of preeclampsia: current concepts. Am J Obstet Gynecol 1998; 179:1359-1375.

6. Bar-Or D, Lau E, Winkler JV. A novel assay for cobalt-albumin binding and its potential as a marker for myocardial ischemia- a priliminary report. J Emerg Med 2000; 19:311-315.

7. Ustün $Y$, Engin Ustün $Y$, Oztürk O, Alanbay I, Yaman H. Ischemiamodified albümin as an oxidative stress marker in preeclampsia. J Matern Fetal Neonatal Med 2011; 24:418-421.

8. Reddy VS, Duggina P, Vedhantam M, Manne M, Varma N, Nagaram S. Maternal serum and fetal cord blood ischemia modified albümin concentrations in normal pregnancy and preeclampsia: a systematic review and meta-analysis. J Matern Fetal Neonatal Med 2018: 31:3255-3266.

9. Noris P, Melazzini F, Balduini CL. New roles for mean platelet volüme measurement in the clinical practice? Platelets 2016; 27:607-612.

10. Reese JA, Peck JD, Yu Z, Scordino TA, Deschamps DR, Mclntosh $\mathrm{JJ}$, et al. Platelet sequestration and consumption in the placental intervillous space contributr to lower platelet counts during pregnancy. Am J Hematol 2019; 94:E8-E11.

11. ACOG Practice Bulletin No. 202:Gestational Hypertension and Preeclampsia. Obstet Gynecol 2019; 133:1.

12. Gioia S, Piazze J, Anceschi MM, Cerekja A, Alberini A, Giancotti A, et al. Mean platelet volume: association with adverse neonatal outcome. Platelets 2007; 18: 284-288.

13. Alkholy $E$, Farag $E$, Behery $M$, Ibrahim M. The significance of platelet count, mean platelet volume and platelet width distribution in preeclampsia. Al-Azhar Assiut Medical Journal 2013; 11:200-214.

14. Usher R, McClean F. Intrauterine growth of live born Caucasian infants born between 25 and 44 weeks of gestation. J Pediatr 1969; 74:901-910.

15. Abboud H, Labreuche J, Meseguer E, Lavallee PC, Simon O, Olivot $J M$, et al. Ischemia modified albümin in acute stroke. Cerebrovasc Dis 2007 ; 23:216-220.

16. van Rijn BB, Franx A, Sikkema JM, van Rijn HJ, Bruinse HW, Voorbij HA. Ischemia modiefied albümin in normal pregnancy and preeclampsia. Hypertens Pregnancy 2008; 27:159-167. 
17. Ozdemir ÖM, Ozdemir E, Enli $\mathrm{Y}$, Oztekin O, Ergin H. Ischemia modified albümin in preterm infants born to mothers with preeclampsia. Pediatr Int 2018; 60:553-559.

18. Delic R, Stefanovic M. Statistical regression model of standard and new laboratory markers and its usefulness in prediction of preeclampsia. J Matern Fetal Nenatal Med 2014; 27:388-392.

19. Iacovidou N, Briana DD, Boutsikou M, Liosi S, Baka S, Boutsikou T, et al. Cord Blood Ischemia-Modified Albumin Levels in Normak and Intrauterine Growth Restricted Pregnancies. Mediators Inflamm 2008; 2008:1-5.

20. Bellos I, Fitrou G, Pergialiotis V, Papantoniou N, Daskalakis G. Mean Platelet volume values in preeclampsia: a systematic review and metaanalysis.Pregnancy Hypertens 2018; 13:174-180.
21. Marumoto $Y$, Kaibara $M$, Murata T. Hemorheological studies on platelet counts and size in normal pregnancy and pregnancies with preeclampsia and IUGR. Nippon Sanka Fujinka Gakkai Zasshi 1989: 41:1380-1386.

22. Cekmez F, Tanju IA, Canpolat FE, Aydinoz S, Aydemir G, Karademir $\mathrm{F}$, et al. Mean Platelet volume in very preterm infants: a predictor of morbidities? Eur Rev Med Pharmacol Sci 2013; 17:134-137. 